\title{
Effect of Expanded Hemodialysis on Body Composition and Nutritional Status
}

\author{
Mohamed Belmouaz Marc Bauwens Estelle Desport Pierre Jamet \\ Frank Bridoux \\ Department of Nephrology Hemodialysis, Poitiers University Hospital, Poitiers, France
}

Dear Editor,

Protein energy wasting (PEW), defined as loss of muscle mass and fuel reserves of the body, is a frequent and deleterious complication in hemodialysis (HD) patients. Several factors, including inflammation, retention of middle molecule uremic toxins, and dialysis procedure contribute to PEW [1]. HD with medium cut-off (MCO) dialyzer has demonstrated efficient depuration of middle uremic toxins and reduced inflammation [2, 3], which may have beneficial effects on PEW. To test the hypothesis that MCO-HD may positively affect body composition and nutritional status in HD patients, as compared to high-flux (HF) HD, we performed a 12-month single-center retrospective pilot study. Patients were recruited from the cohort of 40 patients evenly distributed on MCO-HD and HF-HD in a previous randomized study [4] and then continued maintenance HD using the same dialyzer as allocated after randomization. Among these patients, 16 patients (8 on $\mathrm{MCO}-\mathrm{HD}$ and 8 on HF-HD) receiving $4 \mathrm{~h}$, thrice weekly $\mathrm{HD}$ sessions using bicarbonate and citrate-containing acetate-free ultrapure dialysate were retrospectively analyzed (Table 1). All had a minimum of 12 months of
Table 1. Patient characteristics at baseline

\begin{tabular}{lcc}
\hline & $\begin{array}{l}\text { MCO-HD } \\
(n=8)\end{array}$ & $\begin{array}{l}\text { HF-HD } \\
(n=8)\end{array}$ \\
\hline Age, years & $76 \pm 7$ & $73 \pm 9$ \\
Sex (female/male) & $2 / 6$ & $3 / 5$ \\
Dialysis vintage, months & $31(14-92)$ & $44(35-79)$ \\
BMI, kg/m ${ }^{2}$ & $28 \pm 3.3$ & $29 \pm 4.2$ \\
Residual urine output $<200$ mL/day, $n$ & 8 & 8 \\
CKD etiology, $n$ & & \\
$\quad$ Nephrosclerosis & 3 & 4 \\
$\quad$ Diabetic nephropathy & 1 & 2 \\
$\quad$ Interstitial & 3 & 1 \\
$\quad$ Unknown & 1 & 1 \\
Comorbidity, $n$ & & 4 \\
$\quad$ Diabetes mellitus & 3 & 4 \\
$\quad$ Hypertension & 5 & 4 \\
$\quad$ Heart disease & 3 & 2 \\
$\quad$ Cerebrovascular disease & 1 & 4 \\
Peripheral vascular disease & 2 & 4 \\
Vascular access, $n$ & & \\
$\quad$ Arteriovenous fistula & 5 & \\
Tunneled catheter & 5 &
\end{tabular}

Quantitative data are expressed as mean \pm SD or median (IQR). MCO, medium cutoff; HF, high flux; HD, hemodialysis.
Mohamed Belmouaz CHU POITIERS 
Table 2. Effect of MCO-HD and HF-HD after 12 months on body composition and biological nutritional parameters

\begin{tabular}{|c|c|c|c|c|c|c|}
\hline Parameters & Treatment & Baseline & Month 12 & $\begin{array}{l}\text { Mean values } \\
\text { comparison, } \\
p \text { value }\end{array}$ & $\begin{array}{l}\text { Variation rate } \\
\text { from baseline, } \\
\%\end{array}$ & $\begin{array}{l}\text { Variation rate } \\
\text { comparison, } \\
p \text { value }\end{array}$ \\
\hline SMI, $\mathrm{kg} / \mathrm{m}^{2}$ & $\begin{array}{l}\text { MCO-HD } \\
\text { HF-HD }\end{array}$ & $\begin{array}{l}8.7 \pm 1.1 \\
9.2 \pm 1.1\end{array}$ & $\begin{array}{r}9 \pm 0.9 \\
8.1 \pm 1.3\end{array}$ & $\begin{array}{l}0.6 \\
0.2\end{array}$ & $\begin{array}{r}4 \pm 14 \\
-11 \pm 13\end{array}$ & 0.046 \\
\hline LTI, $\mathrm{kg} / \mathrm{m}^{2}$ & $\begin{array}{l}\text { MCO-HD } \\
\text { HF-HD }\end{array}$ & $\begin{array}{l}12.7 \pm 4 \\
15.6 \pm 5.5\end{array}$ & $\begin{array}{l}16.6 \pm 3.9 \\
12.9 \pm 5\end{array}$ & $\begin{array}{l}0.2 \\
0.4\end{array}$ & $\begin{array}{r}36 \pm 37 \\
-12 \pm 31\end{array}$ & 0.013 \\
\hline FTI, $\mathrm{kg} / \mathrm{m}^{2}$ & $\begin{array}{l}\text { MCO-HD } \\
\text { HF-HD }\end{array}$ & $\begin{array}{l}10.8 \pm 3.7 \\
12.6 \pm 4.3\end{array}$ & $\begin{array}{c}9.9 \pm 3 \\
10.8 \pm 4.1\end{array}$ & $\begin{array}{l}0.6 \\
0.4\end{array}$ & $\begin{array}{r}-6 \pm 20 \\
-11 \pm 23\end{array}$ & 0.6 \\
\hline SMM, kg & $\begin{array}{l}\text { MCO-HD } \\
\text { HF-HD }\end{array}$ & $\begin{array}{l}24.3 \pm 5 \\
25.9 \pm 4.9\end{array}$ & $\begin{array}{l}25.4 \pm 3.9 \\
22.8 \pm 5.2\end{array}$ & $\begin{array}{l}0.7 \\
0.3\end{array}$ & $\begin{array}{r}6 \pm 12 \\
-11 \pm 15\end{array}$ & 0.02 \\
\hline LTM, kg & $\begin{array}{l}\text { MCO-HD } \\
\text { HF-HD }\end{array}$ & $\begin{array}{l}34.4 \pm 9.7 \\
43.1 \pm 14.1\end{array}$ & $\begin{array}{l}44.4 \pm 6.6 \\
35.3 \pm 12.9\end{array}$ & $\begin{array}{l}0.04 \\
0.3\end{array}$ & $\begin{array}{r}37 \pm 36 \\
-14 \pm 30\end{array}$ & 0.008 \\
\hline FTM, kg & $\begin{array}{l}\text { MCO-HD } \\
\text { HF-HD }\end{array}$ & $\begin{array}{l}29.9 \pm 10.9 \\
34.9 \pm 10.8\end{array}$ & $\begin{array}{l}27.2 \pm 8.9 \\
29.3 \pm 9.1\end{array}$ & $\begin{array}{l}0.6 \\
0.3\end{array}$ & $\begin{array}{r}-5.4 \pm 21 \\
-12 \pm 24\end{array}$ & 0.6 \\
\hline Albumin, g/L & $\begin{array}{l}\text { MCO-HD } \\
\text { HF-HD }\end{array}$ & $\begin{array}{r}37 \pm 2.7 \\
39.6 \pm 3.6\end{array}$ & $\begin{array}{l}37 \pm 3.4 \\
38 \pm 2.4\end{array}$ & $\begin{array}{l}0.9 \\
0.3\end{array}$ & $\begin{array}{c}0.6 \pm 15 \\
-4 \pm 6\end{array}$ & 0.4 \\
\hline Pre-albumin, g/L & $\begin{array}{l}\text { MCO-HD } \\
\text { HF-HD }\end{array}$ & $\begin{array}{r}0.3 \pm 0.05 \\
0.33 \pm 0.09\end{array}$ & $\begin{array}{l}0.27 \pm 0.04 \\
0.27 \pm 0.06\end{array}$ & $\begin{array}{l}0.3 \\
0.2\end{array}$ & $\begin{array}{r}-7 \pm 18 \\
-15 \pm 26\end{array}$ & 0.5 \\
\hline $\mathrm{Cr}, \mu \mathrm{mol} / \mathrm{L}$ & $\begin{array}{l}\text { MCO-HD } \\
\text { HF-HD }\end{array}$ & $\begin{array}{l}580 \pm 52 \\
670 \pm 173\end{array}$ & $\begin{array}{l}684 \pm 110 \\
626 \pm 224\end{array}$ & $\begin{array}{l}0.02 \\
0.9\end{array}$ & $\begin{array}{l}19 \pm 24 \\
-6 \pm 22\end{array}$ & 0.044 \\
\hline Total cholesterol, g/L & $\begin{array}{l}\text { MCO-HD } \\
\text { HF-HD }\end{array}$ & $\begin{array}{l}1.54 \pm 0.3 \\
1.56 \pm 0.3\end{array}$ & $\begin{array}{l}1.5 \pm 0.3 \\
1.4 \pm 0.5\end{array}$ & $\begin{array}{l}0.7 \\
0.3\end{array}$ & $\begin{array}{r}-2 \pm 12 \\
-12 \pm 17\end{array}$ & 0.2 \\
\hline Triglycerides, g/L & $\begin{array}{l}\text { MCO-HD } \\
\text { HF-HD }\end{array}$ & $\begin{array}{l}1.5 \pm 0.6 \\
2.3 \pm 0.5\end{array}$ & $\begin{array}{l}1.8 \pm 0.8 \\
1.6 \pm 0.6\end{array}$ & $\begin{array}{l}0.3 \\
0.3\end{array}$ & $\begin{array}{c}30 \pm 108 \\
-19 \pm 49\end{array}$ & 0.2 \\
\hline
\end{tabular}

Quantitative data are expressed as mean \pm SD. MCO, medium cutoff; HF, high flux; HD, hemodialysis; SMI, skeletal muscle index; SMM, skeletal muscle mass; LTI, lean tissue index; LTM, lean tissue mass; FTI, fat tissue index; FTM, fat tissue mass; Cr, creatinine; SD, standard deviation.

follow-up without change in dialyzers or dialysis modality and a multifrequency bioimpedance spectroscopy (BIS) measurements performed at baseline and at 12 months. None of the patients had prescribed oral or intravenous nutritional supplements.

BIS measurements including skeletal muscle (SM), lean tissue (LT) and fat tissue (FT), mass (M), and index (I) were performed at the start of a mid-week HD session (Z-Hydra $^{\mathrm{TM}}$; Meditor, France) at baseline and after 12 months. Routine biological parameters, including albumin, pre-albumin, creatinine $(\mathrm{Cr})$, total cholesterol, and triglycerides were collected at the same time intervals. The variation rate regarding each BIS and biological parameter was calculated by the unit change from baseline to 12 months divided by the baseline value and was ex-

Effect of Expanded Hemodialysis on Body Composition pressed as a mean percentage $\pm \mathrm{SD}$. Comparison between each group was assessed by Mann-Whitney U test. The study was approved by Poitiers Ethics Committee (MR004-3218140520).

Compared to HF-HD after 12 months, MCO-HD improved significantly the variation rate of LTM $(37 \pm 36$ vs. $-14 \pm 30 \%, p=0.008)$, LTI ( $36 \pm 37$ vs. $-12 \pm 31 \%$, $p=0.013)$, SMM ( $6 \pm 12$ vs. $-11 \pm 15 \%, p=0.02)$, SMI ( $4 \pm 14$ vs. $-11 \pm 13, p=0.046$ ), and pre-dialysis serum $\mathrm{Cr}$ (19 \pm 24 vs. $-6 \pm 22 \%, p=0.044)$. Comparison between mean values at baseline and month 12 were only significant for LTM $(p=0.04)$ and pre-dialysis serum $\operatorname{Cr}(p=$ 0.02 ) in MCO-HD. Comparison of FTM, FTI, and other nutritional markers did not show significant difference (Table 2). 
Preventing PEW in HD patients is challenging. Online hemodiafiltration (OL-HDF) may improve PEW by preserving lean body mass probably through decreased inflammation, stimulation of appetite, and better removal of uremic toxins [5]. Compared to HF-HD, MCO-HD as OL-HDF increases removal of higher weight molecules $[6,7]$, which mostly encompass proteins closely related to inflammation and PEW in the uremic milieu. In our previous randomized study, we found that after 3 months, MCO-HD was associated with a decrease in beta2-microglobulin, oxidized low-density lipoprotein, kappa and lambda free light chain pre-dialysis levels, without significant change in other inflammatory, uremic toxins, and oxidative stress biomarkers [4]. Thus, the long-term benefit on body composition may be related to an effect on other non-measured malnutrition biomarkers.

In this study, MCO-HD resulted in an improved variation rate of LTI and SMI which are presumably good surrogate markers of PEW [8], together with pre-dialysis serum $\mathrm{Cr}$ level, whereas other biological parameters appeared less sensitive to denote nutritional changes [5]. Moreover, albumin levels remained stable after 12 months of MCO-HD, suggesting long-term balance between increased albumin hepatic synthesis and dialysate loss.

The present retrospective pilot study is too small and had several limitations, including lack of nutrition con- trol to confirm the beneficial effect of MCO on PEW. However, it showed a promising tendency for MCO-HD to preserve body composition.

\section{Conflict of Interest Statement}

M. Belmouaz and M. Bauwens report having received speaker fees from Baxter, but none related to this study. The other authors have no conflicts of interest to declare.

\section{Funding Sources}

The study did not receive any funding.

\section{Author Contributions}

Co-authors Marc Bauwens, Estelle Desport, Pierre Jamet, and Frank Bridoux were all implicated in this manuscript. Research conception and study design: M. Belmouaz, F.B., M.B., E.D., and P.J.; supervision or mentorship: F.B. Each author contributed important intellectual content during manuscript drafting and accepts accountability for the overall work by ensuring that questions pertaining to the accuracy or integrity of any portion of the work are appropriately investigated and resolved. M. Belmouaz takes responsibility that this study has been reported honestly, accurately, and transparently.

\section{References}

1 Jankowska M, Cobo G, Lindholm B, Stenvinkel P. Inflammation and protein-energy wasting in the uremic milieu. Contrib Nephrol. 2017;191:58-71.

2 Kirsch AH, Lyko R, Nilsson LG, Beck W, Amdahl M, Lechner P, et al. Performance of hemodialysis with novel medium cut-off dialyzers. Nephrol Dial Transplant. 2017;32(1): $165-72$.

3 Zickler D, Schindler R, Willy K, Martus P, Pawlak M, Storr M, et al. Medium cut-off (MCO) membranes reduce inflammation in chronic dialysis patients: a randomized controlled clinical trial. PLos One. 2017;12(1): e0169024.
4 Belmouaz M, Bauwens M, Hauet T, Bossard $\mathrm{V}$, Jamet P, Joly F, et al. Comparison of the removal of uremic toxins with medium cutoff and high-flux dialyzers: a randomized clinical trial. Nephrol Dial Transpl. 2019;35 (2):328-35.

5 Molina P, Vizcaíno B, Molina MD, Beltrán S, González-Moya M, Mora A, et al. The effect of high-volume online haemodiafiltration on nutritional status and body composition: the ProtEin Stores prEservaTion (PESET) study. Nephrol Dial Transplant. 2018;33(7):122335.
6 Ronco C, La Manna G. Expanded hemodialysis: a new therapy for a new class of membranes. Contrib Nephrol. 2017;190(2):12433.

7 Maduell F, Rodas L, Broseta JJ, Gomez M, Xipell M, Guillen E, et al. Medium cut-off dialyzer versus eight hemodiafiltration dialyzers: comparison using a global removal score. Blood Purif. 2019;48(2):167-74.

8 Yajima T, Arao M, Yajima K, Takahashi $\mathrm{H}$, Yasuda $\mathrm{K}$. The associations of fat tissue and muscle mass indices with all-cause mortality in patients undergoing hemodialysis. PLoS One. 2019;14(2): $\mathrm{e} 0211988$. 